\title{
'Reality' in TV Journalism: Dramaturgy of the Motor
}

\author{
About the Relationship between TV Journalistic \\ Production and Dramaturgy in Current Affairs Features
}

\author{
Kenneth Reinecke Hansen
}

As a lead-in to a feature titled 'Inside Big Brother' (4.22.01, Peter Rundle) on the Danish magazine programme Dags Dato the anchor says:

To judge from the media coverage you would think it was one of the major prison escapes. I'm of course talking about the mutiny around Easter of TvDanmark's Big Brother. The escape has hit all the front pages, and even people who claim to never see the programme have contributed to the debate. In the centre of the media storm is TvDanmark's programme director, Paul Gazan. It was he who shut down the direct transmission when reality inflicted itself on the so-called reality show. And it was he who since then has insisted on telling the public that Big Brother is alive and well. Here in Dags Dato we decided to give the programme director a taste of his own medicine. For a couple of days we turned the hand-held camera on Paul Gazan (my translation).

In this context, most interesting is not that the content of the feature is 'reality', but rather that the feature in itself $i s$ reality, in the sense that Dags Dato uses the same methods as the reality producer does: The editorial staff turns the camera on Gazan himself and exposes him for experimental trials, or put shortly, constructs a new reality within the real reality. In this way the feature is reminiscent of the reality show, not only in content, but also in its method of production and form. This example is naturally rather specific, but it points to a general tendency, as TV journalism - not least in the magazine format - frequently borrows from experiences with 'reality' over the last decade.

Reality shows and TV journalism share the point of view that the occurrences of real life are superior to the imagination - in adapted form, to be more precise. Most people's ordinary life is rather insufficient for a drama-requiring TV audience, and even worse: The dramatic episodes in real life are more than difficult to catch with camera and microphone as they take place in real time. Unless the occurrence is staged, the TV journalists are left to discuss and reconstruct what happened, or to interfere with and influence reality itself. The raw reality is not merely un-dramatic and usually just plain boring - it is simply passé when the TV journalist appears on the spot.

The problem is especially urgent in TV journalism's magazine genres, in this case the current affairs feature, which is features produced in newsrooms by news journalists, but 
with a considerably longer format than a news feature - typically 4-15 minutes. Against the background of an investigation (Hansen, 2001-4) of the relationship between TV journalistic production and dramaturgy in such current affairs features in Danish public service TV, in the following I will encircle why and how 'reality' is an attractive TV journalistic narrative grip in solving or circumventing the problem of the disappeared present tense of news occurrences. My focus is on the experimental reality, and ignores other kinds of 'reality', e.g. that presented in docusoaps.

\section{Constructed Reality - in the Real Reality}

A fundamental question is why the concept is even called 'reality', when it appears so unreal, unrealistic and staged. Isn't it just fiction?

The answer is that it is real enough, but also that it is a sort of laboratory reality in the form of relatively controlled experiments. Biologists' experiments with banana flies aren't fiction either: The banana flies are not actors, and the events are not determined by a script. Of course, the flies can mutate or escape and thereby change or destroy the experiment, and then the 'reality' reality overflows its own banks - just as in the Big Brother escape referred to. In this article, 'reality' is defined as a sequence of productionally and textually anchored narrative grips on the reality to be described.

More generally, experimental reality is understood as an independent major genre between fact and fiction. In this sense, reality is reminiscent of the major genre of faction (Larsen, 1995(1990)). But whereas faction retells and reconstructs reality with help from fictitious inspired narrative grips, the 'reality' major genre goes a step further and interferes directly with reality or constructs an entirely new one. Thus we can enumerate four major genres with varying reality reference and interference with reality ${ }^{2}$ :

Illustration 1. Four Major Genres' Reality Reference and Interference

\begin{tabular}{|l|l|l|}
\hline Major genre & Reality reference & Interference with reality \\
\hline FACT & anchored & reporting (minimal interference) \\
\hline FACTION & staged: reconstructed & reconstruction and re-enactment \\
\hline REALITY & staged: constructed & interference and construction (maximal interference) \\
\hline FICTION & suspended & (no interference, but creation of a fictitious universe) \\
\hline
\end{tabular}

TV journalism - which is fact reporting, by definition - has absorbed experimental reality as a tendency because of the production process. The production of TV journalism is subject to some quite special conditions, which separates it from all other kinds of journalism, because it reports with reality as concrete material. The news-provoking occurrence itself has usually disappeared when the journalist makes it to the spot, so the journalist is left to reconstruct it in voice-over and interviews, making it difficult to honour the TV medium's requirement of chronology and documentation with pictures. The missing or broken chronology means not least that TV journalism lacks a permanent need of drive, understood as "the audience's feeling of being forced step-by-step to follow a course of action in a story to its end". (Larsen, 2002:78, my translation). And since the news object is gone, TV journalism lacks concrete visual documentation in the form of visual proof and, generally speaking, pictures that contribute to the reconstruction of the 
occurrence being described - technically speaking, pictures that function not simply as illustrative wallpaper, but that unite isotopically with the voice-over (Hjarvard, 1993).

In production, TV journalism is exposed to a double mediation in its intercourse with reality. This means that something concrete - physically existing - has to be caught on camera and microphone in the primary mediation and adapted in research and editing, the secondary mediation. Thus the feature is always a compromise between reality's forming of the production conditions and the possible content on the one side, and the journalistic forming of the final product's actualised content on the other. Put simply, the process from occurrence to feature looks like this:

Illustration 2a. The Double Mediation of TV Journalism

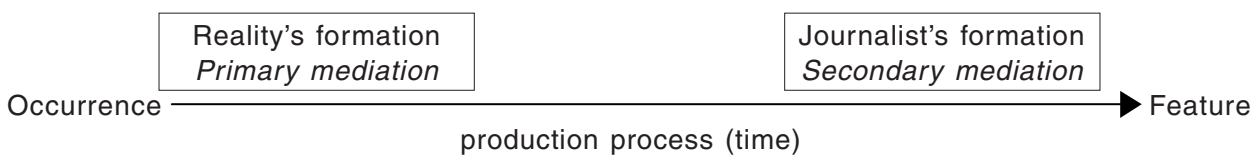

Primary mediation is a special characteristic of the production of TV journalism compared to, e.g., newspaper journalism. The TV journalist is entirely dependent on recordings in the field. And since her fundamental dramaturgical problem is that occurrences' "own" pictures and chronology in the most cases are gone, she has to reconstruct the occurrence using words, sounds and new pictures. 'Reality's formation' states her possibilities and limitations, the potential of the feature, which the 'Journalist's formation' actualises. Following the logic of the model, the journalist is basically located in secondary mediation - more literally non-field in the research phase in the editorial office. Generally, she holds a crucial role in both mediations. In addition, camerawork plays the main role in primary mediation, while research and editing is most important in secondary mediation. Illustration 2 a can thus be specified:

Illustration 2b. The Double Mediation of TV Journalism

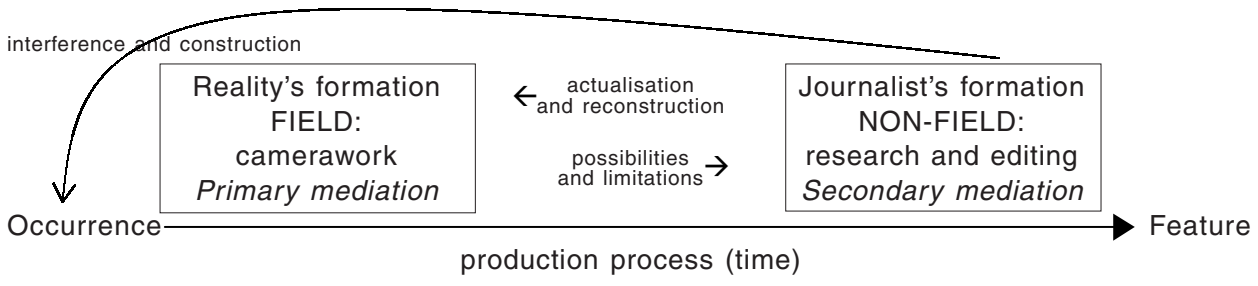

To be able to tell the story on TV - to circumvent the 'Reality's formation' - the TV journalist has fundamentally two possibilities of reaching into, or back into, reality's material: She can seek to reconstruct the occurrence with help from the classical news dramaturgy's voice-over, interviews and pictures ('the faction operation' ${ }^{3}$ ), but she can also reach directly into - or downright construct - the occurrence itself ("the reality operation'). 'Reality' in TV journalism means that the journalist tells about reality by reaching into it - the same way the biologist has to stage and influence a piece of banana fly reality to be able to have insight into or describe the banana flies at all. 


\section{From News- to Magazine-dramaturgy: The Requirement of a Motor}

In the TV journalistic main genre - the news feature - you can mostly be content with actualising the material provided by the primary mediation. The current affairs feature also has a core of news dramaturgy, but beyond this the magazine journalist has to carry out especially profound dramaturgical considerations - as opposed to journalistic considerations in the initial research. The viewer is simply lost if the drive is too low in a current affairs feature. Here, the possibility of establishing a motor is an essential and genre-defining characteristic of the magazine-dramaturgy. The motor is an (interfering) dramaturgical grip that can be crucial to whether or not a story is told ${ }^{4}$. The word 'motor' is the journalists' own (emic) concept and associates exactly to the drive problem. An actual motor (or engine) makes the machinery move forward - but is in a sense subordinate in itself.

In features, a motor can be defined as a recurrent narrator plot that binds the journalistic content together in a scenic and chronological reportage course with the aim of producing drive understood as sequences of expectation/redemption and set-up/pay-off. For now, narrator plot can be defined as a course of actions constructed by the journalist.

However, there must be a distinction between such a chronology structuring dramatic reportage motor, which takes place in sound bites, and a rhetorical motor, where recurrent question-answer sequences structure the feature. The rhetorical, however, is a kind of minimum solution as motor, because it can never produce drive in scenic courses of action. In 'Inside Big Brother' there is clearly a dramatic reportage motor, but this motor is also rhetorical, since the feature seeks an answer to the question of whether Gazan can handle his own medicine, as articulated in the lead-in and as the feature will show. Generally, the motor is almost always established in the lead-in - and rhetorical motors often only in the lead-in together with the answers given/shown along the way and in climax. Below, the focus is on the genuine motor, the reportage motor, which requires journalistic interferences with the material of reality.

\section{The Drive of the Motor}

Thus, a motor has to contribute to the drive of the current affairs feature, but since information comes before drama in all TV journalism, the dramaturgical requirements are often quite modest. On the micro level of the drive the motor must force chronological action scenes, i.e. sound bite sequences in which the action takes place dramatically in a running now. Most sequences in a TV journalistic feature consist of logically structured explanations - arguments, chains of reasoning, points of view, assessments, etc. - to which the action scenes must provide or illustrate the point being discussed. Ideally, the feature alternates between explanations and action scenes.

On the macro level of the drive, the motor must provide one long, upward rising and chronologically organised curve aiming at a culmination in climax: one or more major payoffs to the set-ups of the motor. For such a curve, the feature motor must at minimum provide:

- an establishment in a set-up: in the feature's hook and presentation (possibly only in the lead-in) - with the aim of framing the feature and raising expectations for

- a redemption in a pay-off: the culmination in the feature's climax and wrap.

Between these two points, the feature can leave the motor - permanently or partly. If a motor is only established and redeemed, then it merely functions as an outer frame. In 
'Inside Big Brother' the camera follows Gazan throughout, but every now and then the motor is suspended, especially when pictures from the passing week are shown or when Gazan in interviews reflects on the escape from the house, the reactions of the press, and so on. In other words, the feature jumps between the scenic-chronological motor level and the un-chronological content level. In between, the journalist communicates the jump in his voice-over, here from motor to content: "But if Paul Gazan has problems with the camera [the motor], he doesn't lack words when it comes to the media's treatment of the Big Brother crisis... [the journalistic content]" (my translation). The feature has no genuine climax, e.g. in the sense of Gazan wanting the experiment to end. Therefore, the journalist also has to dismount the motor himself in the final voice-over: "And here we take pity on the programme director and let him have his life back" (my translation). Characteristically, voice-overs related to the motor are in the present tense.

'Clothesline' is one of many synonyms for the motor, and this illustrates the mechanism well: The journalistic content is "hung up" on the recurrent motor. In other words, the motor constitutes a story in the story, by which it separates an independent narrator level from the journalistic content's level. And this is a dramaturgic advantage: The journalistic content often has to be told or retold in a circular dramaturgy low on drive because it is abstract and/or without immanent chronology. As compensation, the motor on the narrator's level implements a more linear dramaturgy with its characteristic principle of increasing excitement and development. A narrative structure is thereby constructed on the outside of or through the content's more circular structure. In 'Inside Big Brother' the journalistic content is the Gazan portrait, consisting mainly of interviews and old pictures, to which the motor provides the drive by following him with a handheld camera from beginning to end.

To summarize, the motor has the double drive function, in that it, firstly, compensates for and alternates with the many dramaturgical declines in the journalistic content by forcing action scenes (: micro drive) and, secondly, establishes a carrying chronology, for the journalist to cut into and out of on the way to the culmination in a climax (: macro drive). Illustration 3 shows this general connection between a (reportage-) motor and the journalistic content (see also the illustration principles in Larsen, 2003):

Illustration 3. The Dramaturgic Relations between (reportage-) Motor and Journalistic Content

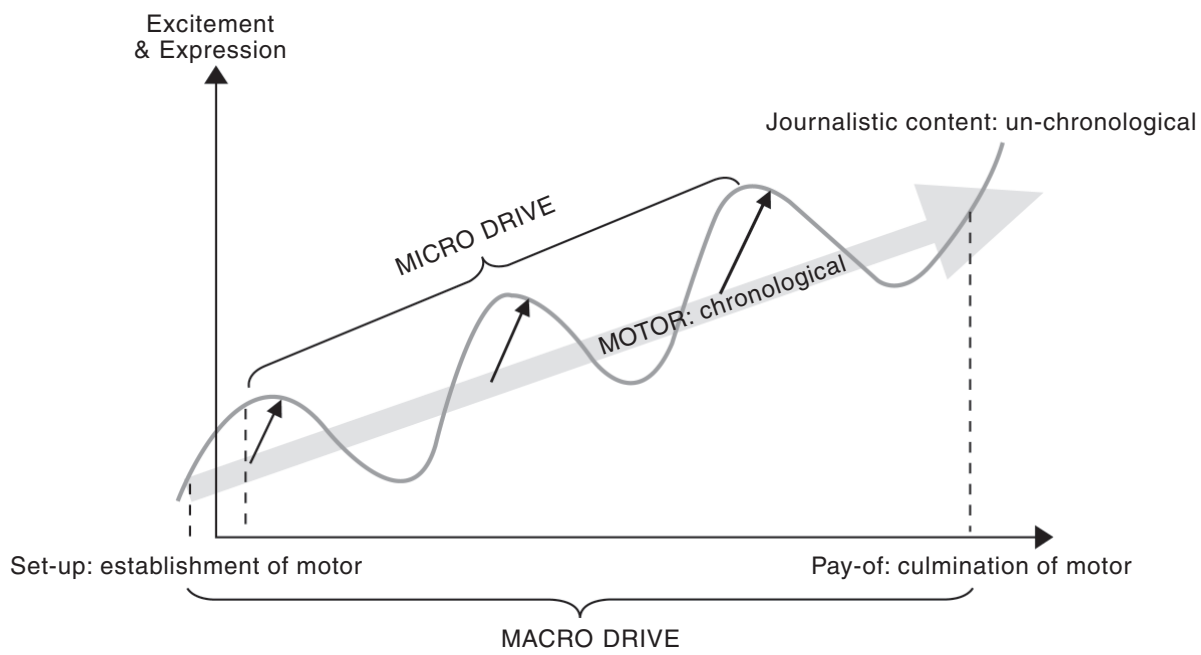


With relatively simple means, the motor can meet the TV media's immanent requirement of increasing excitement. And conversely, an unsuccessful establishment or redemption can cause the entire feature to be dropped. As an example, a feature about Danish politician Poul Nyrup Rasmussen's survival as President of the Social Democracy was dropped because Dags Dato was hindered in filming him in his hotel room while writing his "fatal speech" to the party congress. All media had access to the actual presentation of the speech, and the Social Democrat delegates were more than willing to give interviews. But to place the speech in a climax, Dags Dato needed the writing process itself, and thereby the born chronology up to the speech. From the beginning, the feature was to establish a scenic Nyrup motor for the journalist to cut into and out of in a course of events to culminate in a climax. When the journalist in her persuasion attempt explained to Nyrup's spin-doctor that "we have to have more than the news," this 'more' referred to the (establishment of the) reportage motor.

\section{The Fine Mechanics and Components of the Motor}

The motor functions as a metonymy on the journalistic angle ${ }^{5}$. In the narratological sense, the motor is the feature's carrying plot and consists in itself of one or more plots, which are the journalist's concrete tools for reaching into reality. In fiction the plot is synonymous with discourse in the narratological approach ${ }^{6}$ and can be defined

as that course of action in the story the writer has constructed to force the carrying character though one or more fateful turning points - all the way to the final and fate-decisive turning point that releases the story in a climax. The plot with its turning points - reversals, rebounds, sharpenings - is the main source of the story's drive. (Larsen, 2002:83, my translation)

In fact genres, it is self-evidently unacceptable to construct an entirely new reality with the help of a script and actors in this way, but journalists have developed a set of tools that is reminiscent of the fiction plot. Roughly, there are two possibilities: Either the reality itself can contain an intrigue plot, which journalistically speaking is a gift located in the primary mediation. Or the journalist can establish a narrator plot in the secondary mediation, which is, journalistically speaking, interference. Intrigue plots are most reminiscent of fiction plots and appear when reality's own stories are plotted from the beginning (Larsen, 1995(1990):105). Thus, the intrigue plot is out of the journalist's control - although she can naturally provoke an intrigue with the help of a narrator plot or act as one of the parts in the intrigue. When the journalist herself establishes a plot, it receives a different character than in fiction and intrigue - as an "extra reality level" - but with the same function, namely drive. Larsen discusses narrator plot "when it is the producer of a fact or entertainment programme who stages and records a course of actions and events in reality". (2002:83, my translation), and furthermore separates these in journalistic plots and entertainment plots. The journalistic plots are divided into three main groups (p.84-5):

1) Staging of the journalist herself, i.e. the plots stand up; journalist as guinea pig; journalist as explorer; journalist as truth hunter (with the subordinate plots candid camera; undercover; agent provocateur; gate crashing; anonymous witness; interview with trump; try-out) 
2) Staging of participants, i.e. the plots confrontation of participants; participants as guinea pigs; surprising provocation; the third gadget; distracted interview; conducted tour in own universe; back to the spot

3) Construction of a chronological course of actions, i.e. the plots follow the process to the moment of truth; construction of new reality; reconstruction and re-enactment (my translation).

A (reportage-) motor in current affairs features consist almost by definition of type 3 ) construction of a chronological course of actions, but in most cases this construction will be built up using experimental helping plots from group 1),2) or both. For the sake of identification a feature needs a case, which again can be combined with staging of the journalist herself. In this way, 'Inside Big Brother' pulls on a larger plot repertoire in the motor construction: Paul Gazan is exposed to almost all of the staging of participants plots, but with Dags Dato and the journalist as agent provocateur, a plot rhetorically formulated in the lead-in - "Here in Dags Dato we decided to give the programme director a taste of his own medicine" - leaving tracks in the feature, as the journalist supplies Gazan with buttonhole microphone, whereby the motor is established visually. Incidentally, it would have been a motor nonetheless even if Dags Dato had merely followed Gazan for a couple of days, because it would then have been the participants plot conducted tour in own universe. It is, however, the 'reality'-inspired experiment with Gazan that makes the motor also journalist carried.

\section{Participants as Motor}

The reportage motor inlays a story in the story, which causes the narrator's level to be momentarily separated from the level of the journalistic content. In 'Inside Big Brother' the content is structured around a portrait of Paul Gazan, who in the past week has been the centre of media attention. The potential conflicts and goals of the case can be illustrated in the actant scheme ad follows.

Illustration 4a. Actant Scheme for the Journalistic Content's Level

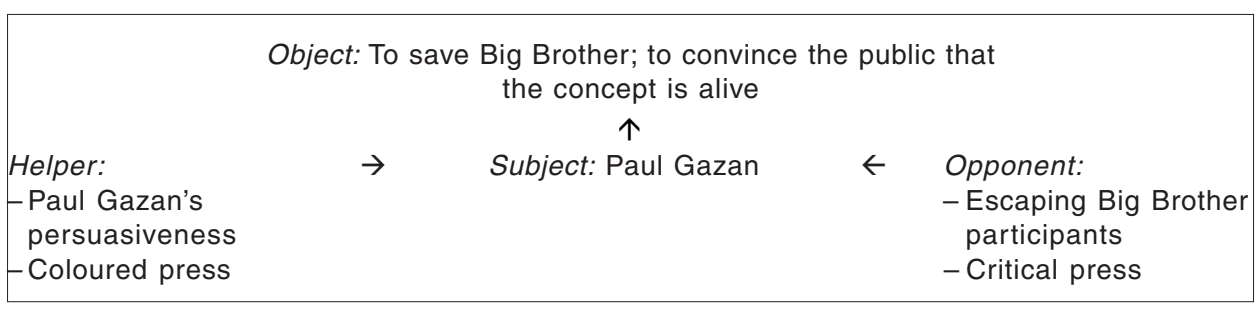

Problematically, this story can only be told in past tense with unconnected archive pictures, and there is no course or drive in a portrait. The events of the week - the Big Brother escape - can of course be retold chronologically, but in itself a portrait has no time or chronology and can therefore not be forced into a linear dramaturgy. The narrative grip consists of the reportage motor: following Gazan, experimenting "for a couple of days," and exposing him to trials by taking away his private life. That story can be told in running present tense and contains a genuine - inner, psychological - conflict in the elementary excitement and suspense towards the climax: Can he tolerate his own medicine? The actant scheme of the narrator's level, on which the journalistic content is hung, appears as follows: 
Illustration 4b. Actant Scheme for the Narrator Level (carried by the reportage motor)

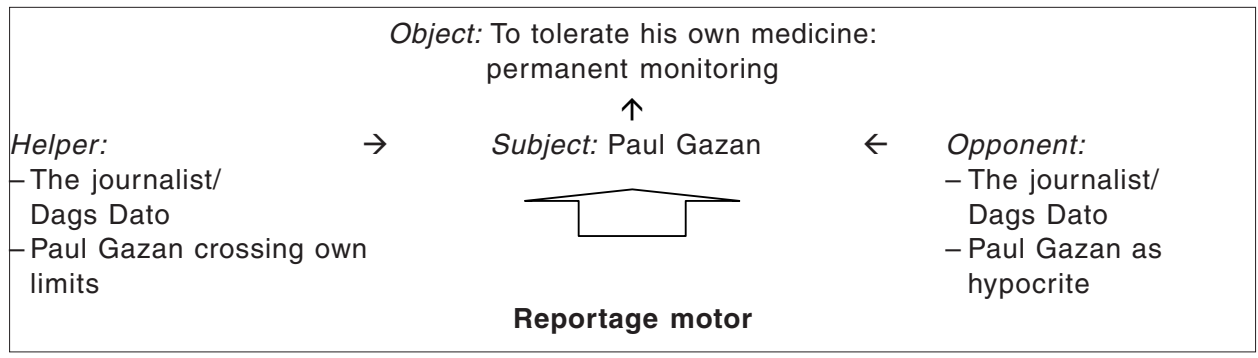

The journalist functions almost by definition as opponent, because his experiments oppose Gazan. In this case, however, the journalist also functions as helper, because a "friendly" motor is being used. Bottom line, this is a gag, not intending to counteract Gazan's image.

Gazan assumes the subject position in both actant schemes, which is quite normal when a participant is a motor himself. Dramaturgically a journalist will often prefer that the main character is thus "his own motor". The experiment draws a more nuanced portrait of the programme director compared to a feature consisting solely of interviews and voice-over on the level of journalistic content. For all practical purposes the motor is both a narrating grip and a crucial part of the content in this feature.

\section{The Journalist as Motor}

It is at least as common that the TV journalist functions as motor and thereby assumes the subject position on the narrator level. In these instances, the journalist makes a virtue of necessity: The difficulties in telling the story become the narrating principle in itself. In this way the double mediation is laid bare, which not least gives a feature the opportunity of "excusing" the resistance of reality and prospective holes in the dramaturgy. The viewer receives epic impressions in the Brecht sense, because the production process and the narrating itself leave indexical tracks. Since the viewer gains an insight into the journalistic methods, the journalist motor strengthens the credibility in hard, revealing journalism. This type of motor is, however, pure form and in many cases a dramaturgic emergency solution since reality doesn't get a chance to "show itself". The participants risk becoming walk-ons in the journalist's narration, which can weaken the identification.

Contrary to a participant motor, the journalist motor can be carried forward by the lead-in and voice-over, whereby it approaches the rhetorical. This typically happens if the drive and news value in the material of the primary mediation is too weak. Narrating becomes the occurrence itself, or at least a main part of it. The journalist will typically be lifted forward in the lead-in as the motor is established - "Our reporter So-andso went... when..." - whereby it raises the expectation that the viewer will receive the result of the hunt on the way and not least in the $\operatorname{climax}^{7}$ (see also Hansen, 2001). Moreover, the journalist can stage herself and her activities in the picture, but this isn't strictly necessary. On the other hand, this type of story certainly places great demand on the journalist as narrator (-voice).

\section{Entertainment Plots}

The fluid border between fact and entertainment in TV journalism shows concretely in the other type of narrator plot, entertainment plots, i.e. "“artificial' courses of action with 
active participants, which are staged first and foremost to optimise excitement - but only 'for fun' - in the programme". (Larsen, 2003:367, my translation). Specifically, entertainment plots include: competition, assignment, riddle, challenge, temptation, trial, transformation, unexpected guest, time limit, chance and ballot (ibid, p.367-8, my translation). This type of plotting - a rather straightforward 'reality' phenomenon - exists only in very soft features and is always inferior to the journalistic plots. The motor in 'Inside Big Brother' is supported by the entertainment plots trial and temptation.

\section{Reality Journalism - 'Reality' Serving Journalism}

In this article, the recurring example has been a quite obvious staging and motor - and explicitly 'reality' - but it was chosen to illustrate a general tendency. In the same way that faction began in TV journalism of the 1980's as avant-garde currents that eventually became mainstream, the 'reality' tendency is coming through as well established narrative grips. And it is only a tendency: Pure experimental reality occurs only when the entire occurrence has been staged in favour of the camera, and this happens very rarely in TV journalism and then only in very soft features. For Big Brother and similar shows the real reality is inferior to the experiment, whereas reality journalism must always place the experiment inferior to reality. What the aim in itself is in the reality show is only a means in TV journalism. Even in 'Inside Big Brother', the aim is the journalistic portrait. In sum, the aim-/means-structure of this feature looks as follows - since the motor consists of a conglomerate of plots with the aim of creating chronology:

- Aim at the journalistic content's level: the story itself, which is a portrait of Paul Gazan in "the real reality"; it is told in an un-chronological and circular dramaturgy linked by voice-over, interviews and archive pictures.

- Means at the narrator level: the story in the story, i.e. the reportage motor, which is a constructed reality told in running present tense in an excitement-building linear dramaturgy consisting of action scenes. The motor is a construction of:

\section{- Aim: construction of a chronological course of actions}

- Means: Varying staging of participants plots with support from the journalist as agent provocateur and the entertainment plots trial and temptation.

TV journalism has armed itself with reality tools to overcome and solve the problem of double mediation in TV production. In longer features, the journalists have apparently taken partiality for a recurrent dramaturgic motor to support the journalistic content. The current affairs feature thereby extends the classical core of news dramaturgy and becomes a narrative - or rather also a narrative. Whereas the journalistic content serves the viewer's thirst for knowledge, the motor meets the viewer's narrative desire (Brooks, 1984; Christensen, 1996). The well-organised current affairs feature provides relevant information and a good story - at the same time.

Paul Gazan - the hard-tried programme director tasting his own medicine - is right in more than one sense when he says in the feature, that "the reality show has overflowed its own banks and has implicated all of us all of a sudden" (my translation). TV journalism's increasing adaptation in the second mediation, made possible by modern editing technology ${ }^{8}$, has moved out into reality itself, the raw material of journalism. Moreover, the journalist is defining new roles for herself, as she increasingly takes on responsibility as narrator - as "institutionalised" in narrative journalism - and as experimenter, as 
in public journalism and the reality journalism discussed here. It obviously holds great communicative advantage to apply narrative principles - but, by nature of the matter, it poses ethical problems as well. It has not been the intention of this article, however, to contribute to an ethical discussion on reality journalism. Instead, the purpose has been to present a textually anchored description device for analysis and understanding of those mechanisms that make experimental reality an attractive narrative grip in TV journalism in general and the current affairs feature in particular.

\section{Notes}

1. Hjarvard (1999) points to a general increase in TV news coverage of culture and universally human topics, and the concrete example is clean up: Dags Dato uses the furore of the passing week as an "alibi" for showing some Big Brother. Such thoughts about content are naturally interesting and characteristic, but not the focus here.

2. I don't consider entertainment an independent major genre, since entertainment in varying degrees is a part of all four major genres, even though "Some has expressed wishes of dividing between journalism and entertainment. This is not a fruitful distinction, because the divide properly goes between fact and fiction - between what is documentary and that which is made up." (Njaastad, 1999:52, my translation).

3. Here 'faction operation' is to be understood very generally as any form of reconstruction of the occurrence. If a train accident is the occurrence then interviews with eyewitnesses is a reconstruction. The interview itself is a kind of faction - in the sense of dramatised reality (Larsen, 1995(1990)). That the interview over time has become a fundamental journalistic genre is a different story.

4. However, dramaturgical criteria can always be overruled by a particularly controversial or interesting journalistic content. Also in current affairs features it applies, that content is king.

5. Another and related principle of connection is characteristic for the current affairs feature, namely the theme consisting of a visual and/or auditory refrain that is reiterated through the feature as metaphor on the journalistic angle. The theme is in family with the motor, and they can merge so the motor has a thematic character and vice versa. But in the functional dramaturgic sense the theme is rather opposite to the motor, because it lacks the drive and chronology of the motor, which is why it is named breaker in the journalist jargon. In return, the theme has the advantage that it doesn't require interference with reality - only with the editing process.

6. Narratologists commonly distinguish between narrative discourse, narrative content or story, and the narrative act (Genette, 1980(1972)).

7. In principle, it is also a - although weak - rhetorical motor when the lead-in is expressed more general, as in "Dags Dato/We went... when..."

8. See for instance Hallin (1992) about the tendency to and consequences of sound bite journalism.

\section{References}

Brooks, Peter (1984) Reading for the Plot. Design and Intention in Narrative. Oxford: Clarendon Press.

Christensen, Robert Zola (1996) 'Vandrehistorier, psykoanalyse og narrativt begær', in Kritik 120.

Genette, Gérard 1980 (1972) Narrative Discourse. Cornell University.

Hallin, Daniel C. (1992) 'Sound Bite News: Television Coverage of Elections, 1968-1988', in Journal of Communication 42.2 (Spring), pp. 5-24

Hansen, Kenneth Reinecke (2001) 'Anders Agger smed mobiltelefonen væk og parkerede uden p-skive. Om fortælledramaturgi i tv-feature', in Apparatur nr. 2, December 2001, Syddansk Universitet 2001, pp. 45-54 (http://www.humaniora.sdu.dk/dansk-kolding/artikler/pdf/andersagger.pdf)

Hansen, Kenneth Reinecke (2001-2004) Tv-aktualitetsfeaturens dramaturgi. Kunsten at etablere en motor (provisional title), PhD dissertation / work in progress, Syddansk Universitet

Hjarvard, Stig (1993) 'Fra opposition til isotopi. En teoretisk og analytisk diskussion af forholdet mellem tale og billede', in Mette Davidsen-Nielsen (red.) Billeder i tale. Roskilde: Roskilde Universitetscenter.

Hjarvard, Stig (1999) TV-nyheder i konkurrence. Frederiksberg: Samfundslitteratur.

Larsen, Peter Harms (1995 (1990) Faktion som udtryksmiddel. København: Forlaget Amanda.

Larsen, Peter Harms (2002) 'Virkeligheden på spil. Iscenesættelse af virkelighed i tv-programmer - fra journalistik til underholdning', in MedieKultur 34.

Larsen, Peter Harms (2003) De levende billeders dramaturgi, Bind 2 - TV, DR.

Njaastad, Olav (1999) Tv-journalistikk - Bildenes fortellerkraft. Oslo: Ad Notam Gyldendal. 